



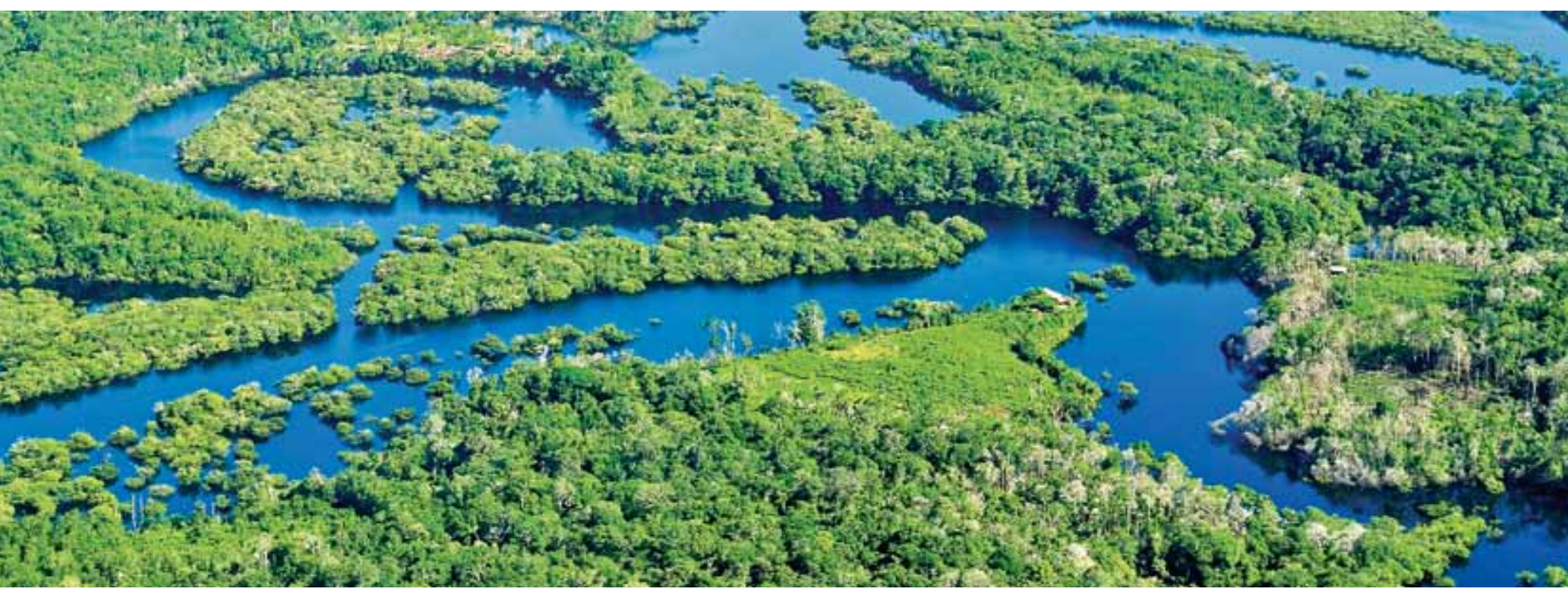

\section{Exploring the pathway: an evaluation of the influence of Forest Day}

Sophie Higman 
(c) 2011 Center for International Forestry Research

All rights reserved

ISBN 978-602-8693-72-1

Higman, S. 2011. Exploring the pathway: an evaluation of the influence of Forest Day. CIFOR, Bogor, Indonesia

Photos: Neil, Palmer/CIAT; CIFOR

Text and layout: Sophie Higman, Green Ink

Cover photo: Aerial view of the Amazon rainforest near Manaus, the capital of the Brazilian state of Amazonas. Neil Palmer/CIAT, 2011.

\author{
CIFOR \\ Jl. CIFOR, Situ Gede \\ Bogor Barat 16115 \\ Indonesia \\ T +62 (251) 8622-622 \\ $\mathrm{F}+62(251) 8622-100$ \\ E cifor@cgiar.org
}

\title{
www.cifor.org
}

www.ForestsClimateChange.org

This brochure has been produced following an evaluation of influence carried out by Green Ink at the request of CIFOR and the Collaborative Partnership on Forests. Green Ink provides a range of communications services for organizations working in sustainable development in agriculture, natural resources and related fields.

www.greenink.co.uk 


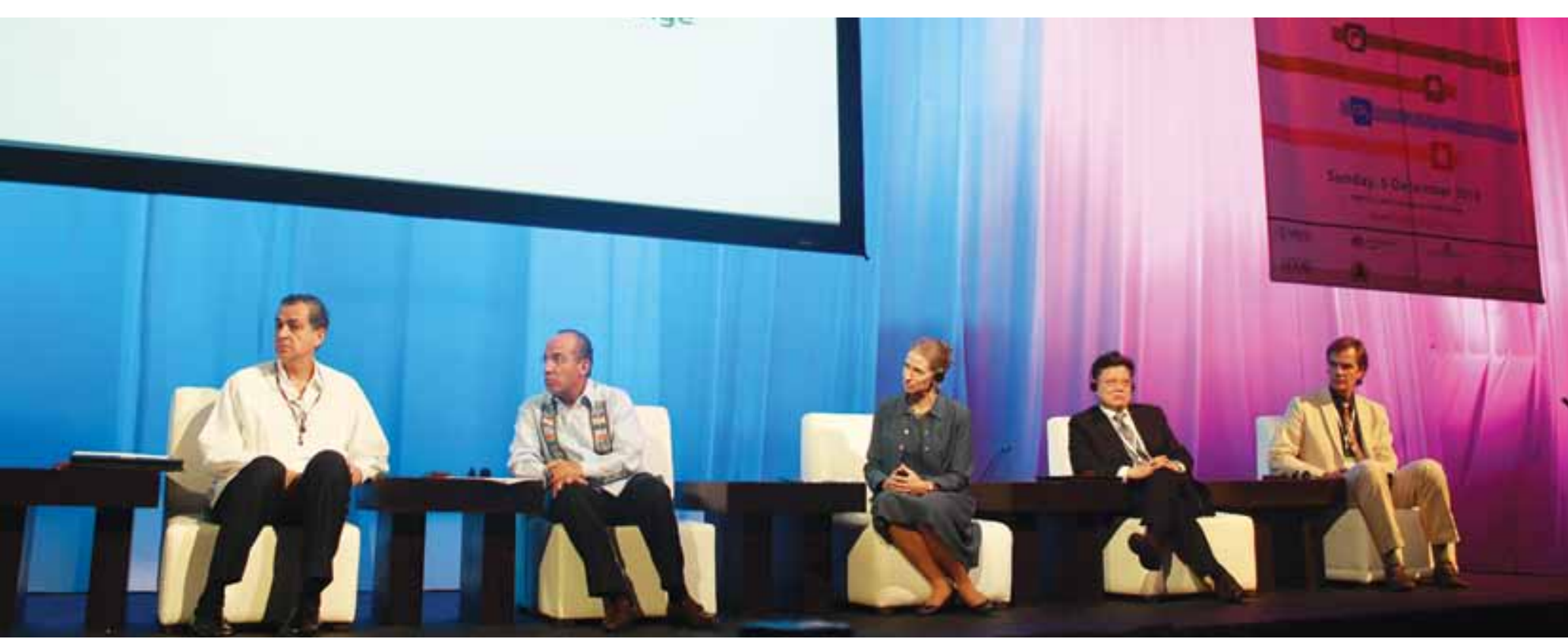

\section{Contents}

Acknowledgements

Key messages

Introduction

1. Who comes to Forest Day and why?

2. Identifying influence

3. Looking to the future 


\section{Acknowledgements}

I would like to thank CIFOR and the Collaborative Partnership on Forests (CPF) for inviting Green Ink to undertake this evaluation. In particular, thanks to John Colmey for his ongoing support and enthusiasm, as well as James Maiden and Daniel Cooney at CIFOR for their practical help and encouragement. My thanks also go to Simon Chater, Nick Pasiecznik and other colleagues at Green Ink for help with interveiws, organizing translations, reviewing interim reports and drafts, and to Paul Philpot at Green Ink for designing the figures.

Finally I would also like to thank all the people who answered questions at Forest Day, the hundreds of people who responded to the internet survey, and those who gave us lengthy and thoughtful responses during telephone interviews. 


\section{Key messages}

An evaluation of the influence of Forest Day was carried out in three phases that included interviews at Forest Day 4, an internet survey and telephone interviews, between December 2010 and June 2011.

- Forest Day is highly appreciated by participants, with $95 \%$ of respondents to the internet survey rating Forest Day 4 as successful or very successful.

- The 1,533 participants at Forest Day 4 came from 109 different countries, with 53\% from developing countries.

- Representatives of non-governmental and governmental organizations together made up nearly 50\% of participants.

- People come to Forest Day to stay up-to-date with new information, for networking, to follow and influence the UNFCCC negotiations, and to disseminate their own information.

- Of 342 respondents to the internet survey, 30\% were members of official UNFCCC delegations, suggesting Forest Day is achieving one of its major aims by drawing in UNFCCC negotiators.

- Among members of official UNFCCC delegations, 85\% said that Forest Day had an influence in shaping their negotiating position or thinking on forestry-related issues. Among all respondents to the internet survey, 69\% credited Forest Day with having an effect on their thinking.

- Interview evidence suggests that Forest Day has been influential in setting the agenda for discussions more broadly on REDD and carbon-related forestry issues, but that this is difficult to separate from other processes and meetings.

- Some projects were identified as having originated from meetings and contacts made at Forest Day, but it is very difficult to attribute a significant influence of Forest Day on project development. 


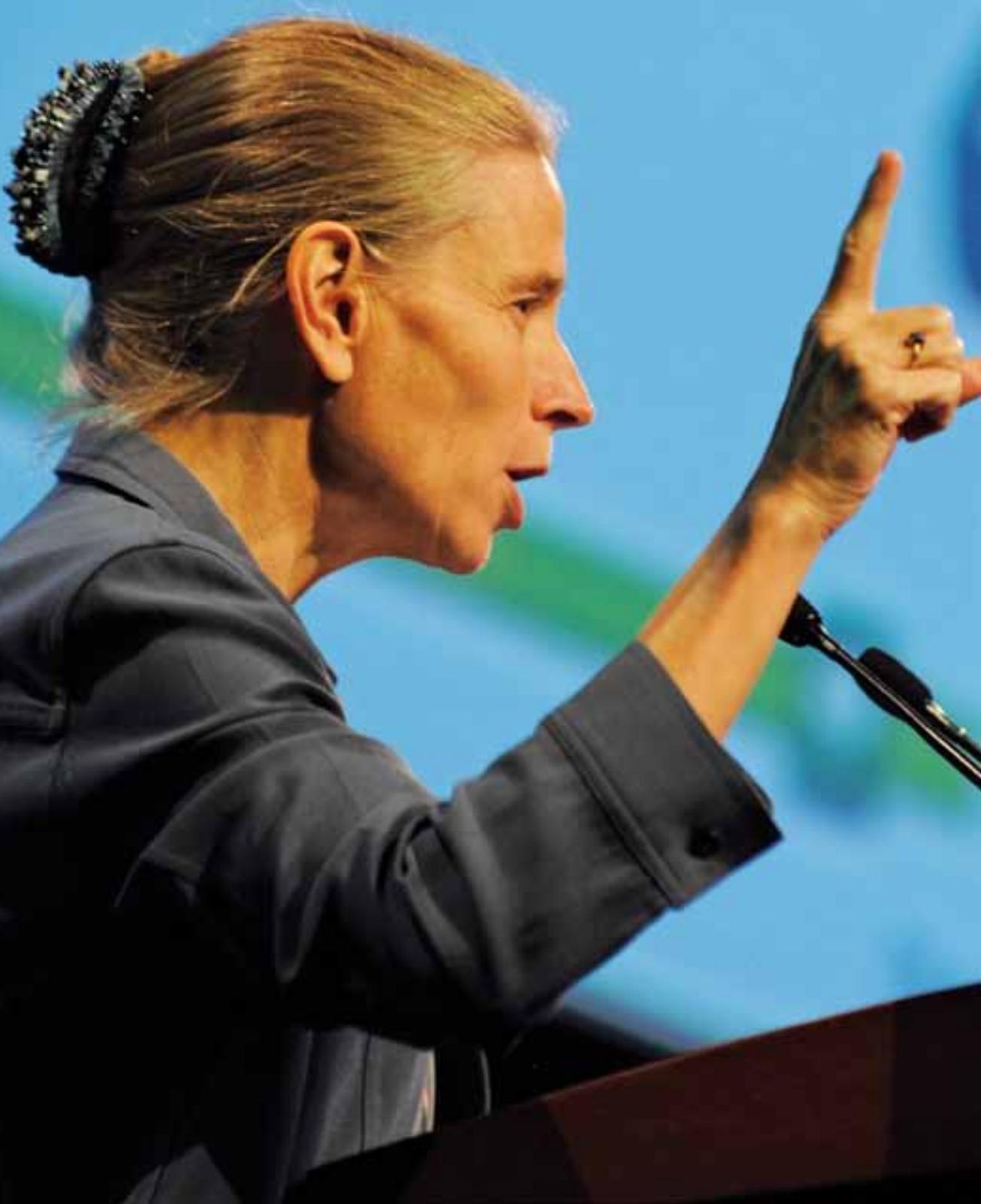




\section{Introduction}

\section{What is Forest Day?}

Forest Day has been held every December for the past four years, to coincide with the Conference of Parties (COP) of the United Nations Framework Convention on Climate Change (UNFCCC).

Organized in the middle of each COP event, it is a day for bringing together the broad sweep of people with an interest in the state of the world's forests, from political leaders to indigenous groups and forest-dependent people, scientists and researchers to policy makers, donors to nongovernmental and intergovernmental groups, and the media.

The event brings some of the world's most influential voices on forests and climate change together with those who are not always heard so clearly. Forest Day has been timed to occur halfway through the COP, and a major aim is to inform UNFCCC negotiators about the role of and potential mechanisms for including forests in the UNFCCC agenda.

CIFOR's Director General, Frances Seymour, welcomes participants at the Opening Plenary of Forest Day 4 


\section{Who organizes Forest Day?}

Forest Day is convened by CIFOR on behalf of the Collaborative Partnership on Forests (CPF) and host-country governments. So far the event has been held in Bali, Indonesia in 2007; Poznań, Poland in 2008; Copenhagen, Denmark in 2009; and in Cancún, Mexico in 2010.

The event has been steadily increasing in size every year, despite greatly varying attendance at the COP itself. At the first Forest Day in Bali, 800 participants highlighted the importance of forests in mitigating climate emissions, and sought to ensure the inclusion of forests in the UNFCCC Bali Action Plan. At the second, the numbers swelled to more than a thousand participants. By Copenhagen in 2009 and Cancún in 2010, Forest Day had evolved and grown

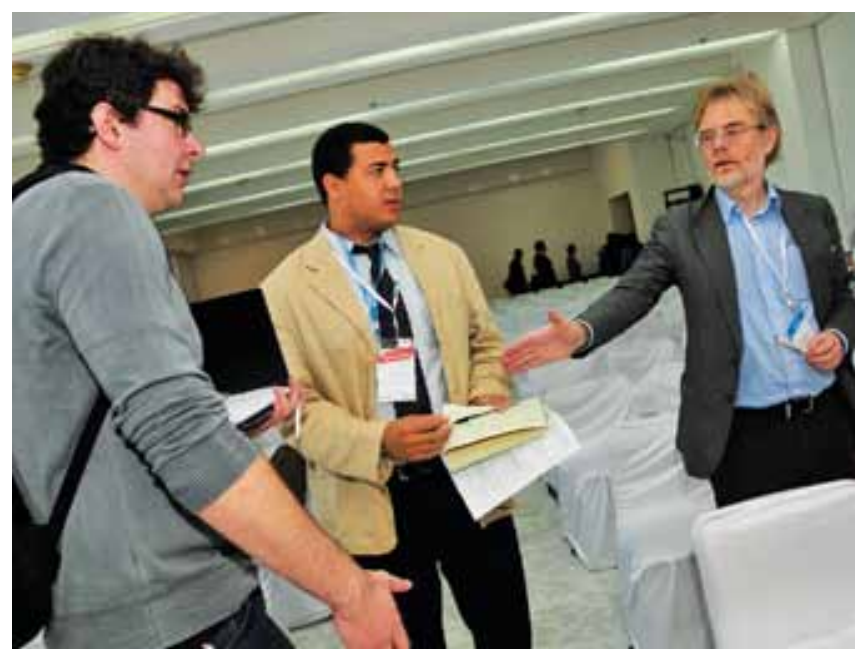

Setting up before a Parallel Learning Event, Forest Day 4 to accommodate some 1,500 participants, making it one of the best attended events in the forestry calendar.

More than three times as many people attended the 2003 COP in Copenhagen $(50,000)$, compared to Cancún in 2004 (16,000). Despite this, attendance at Forest Day was similar in both years - meaning that one tenth of all the people attending the COP in Cancún participated in Forest Day.

\section{What does Forest Day aim to do?}

The organizers and supporters of Forest Day have sought to ensure that forests remain high on the agenda of global and national climate strategies, and that those strategies are informed by the most up-to-date knowledge available.

The role of forests in mitigating and adapting to climate change has remained the central issue for Forest Day, but the specific content and objectives have evolved each year in line with discussions at the COP meetings themselves. Reducing emissions from deforestation and forest degradation (REDD) has been a central theme throughout; in 2010, further emphasis was given to mechanisms for including biodiversity, as well as safeguards, land tenure and rights, as elements in the REDD+ agenda.

UNFCCC negotiators at the COP talks have been an important target audience for Forest Day.

Negotiators are not only responsible for agreeing on critical issues in the UNFCCC negotiations, but are often also key decision makers in their home 
countries, and in the governance of international initiatives. This makes them a key audience for Forest Day messages.

Forest Day aims to influence thinking and actions among a wide range of policymakers, researchers, the media and other opinion leaders. The assessment of influence reported here evaluates the extent to which this objective has been achieved.

\section{About this evaluation}

In December 2010 CIFOR and the CPF asked Green Ink to carry out an evaluation of the influence of Forest Days 1 to 4 . This was undertaken in three phases.

A first round of informal interviews was held with participants attending Forest Day 4 in Cancún in December 2010. The interviews were loosely structured, but focused on eliciting an initial idea of why people come to Forest Day, what they aimed to get out of the day, and what they thought were the wider effects of Forest Day. Interviews were held with 23 speakers, organizers and participants over the course of the day.

Following Forest Day 4, a link to an internet survey in English, French and Spanish, was sent to all participants. The survey was open during January and February 2011, and included a mixture of quantitative and qualitative questions. A total of 342 people responded to the survey - a high response rate, indicating the level of interest in Forest Day.

A further set of interviews was carried out by telephone, Skype and email in May and June

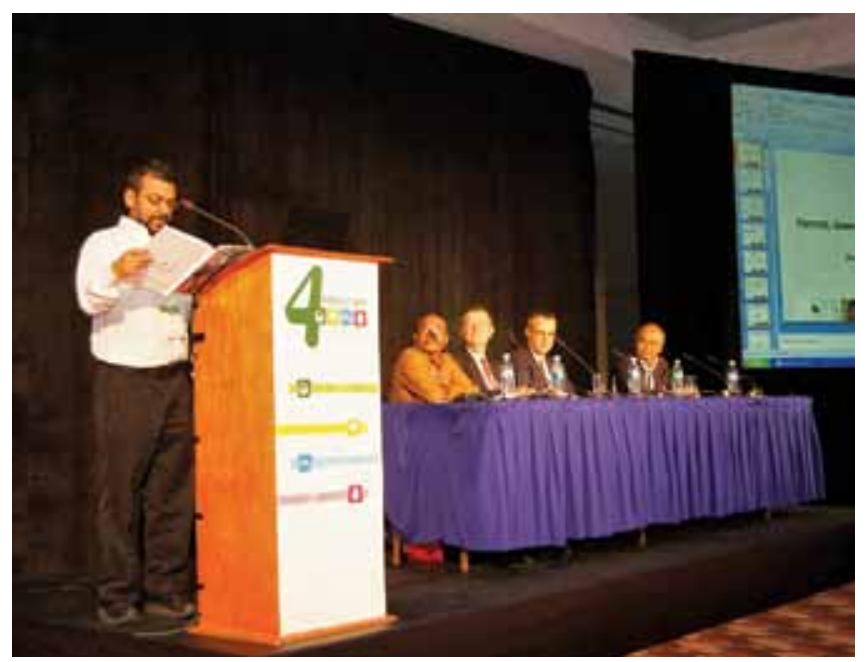

Arun Agrawal, of the University of Michigan, provides the keynote address for a Parallel Learning Event, Forest Day 4

2011. Twenty respondents to the internet survey were interviewed to elucidate their perspectives on Forest Day in more detail. The selection was made on the basis of comments provided in the written survey, particularly where respondents had suggested they might know of specific or significant impacts of Forest Day. It also included those who were members of official UNFCCC delegations and who had reported that Forest Day 4 had a major effect on their thinking or negotiating position.

These interviews sought to pin down more precisely the impacts or influence that they perceived Forest Day to have, and followed a semistructured interview guide. 


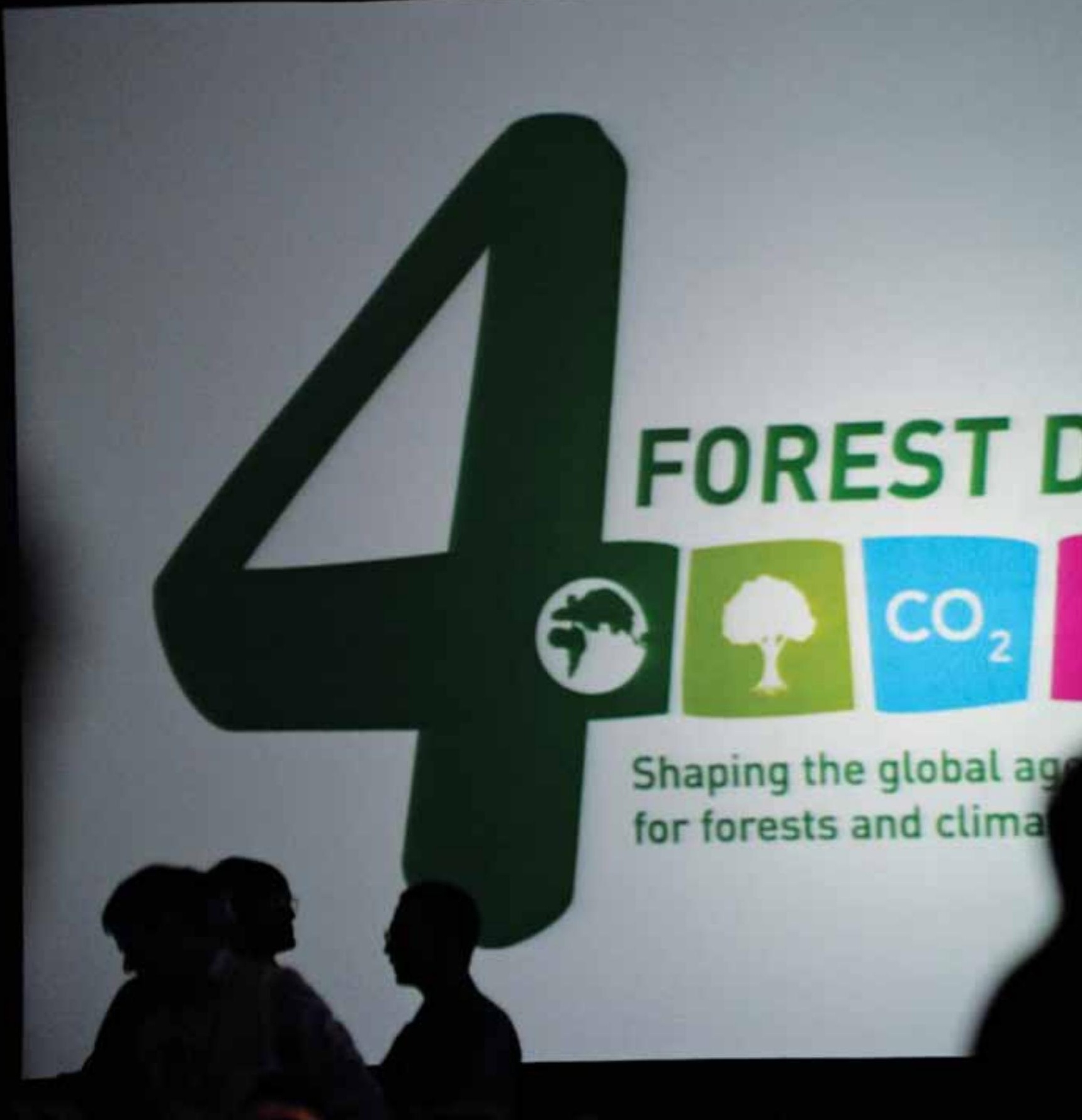




\section{Chapter 1}

\section{Who comes to Forest Day and why?}

\section{Who are the participants?}

More than 1,500 people attended Forest Day 4 in Cancún. Non-governmental organizations (NGOs) were the best represented sector, comprising $31 \%$ of all participants, followed by governmental organizations who made up a further $18 \%$, and universities $12 \%$. Participants came from 109 different countries, and more than 53\% of participants came from developing countries. Over 100 international and national journalists attended Forest Day 4, resulting in more than 400 articles and broadcasts over two days.

Following Forest Day 4, participants were invited to complete the internet survey. In all, 342 respondents completed the survey - more than one in five of those who attended. The breakdown between sectors responding to the survey was broadly similar to that on the day. NGOs and universities were slightly over-represented, with NGOs comprising 37\% of respondents, universities 19\% and government representatives $17 \%$.

The organizers of Forest Day have identified UNFCCC negotiators as a key target audience, as they seek 


\section{Attendance at Forest Day 4 by sector}

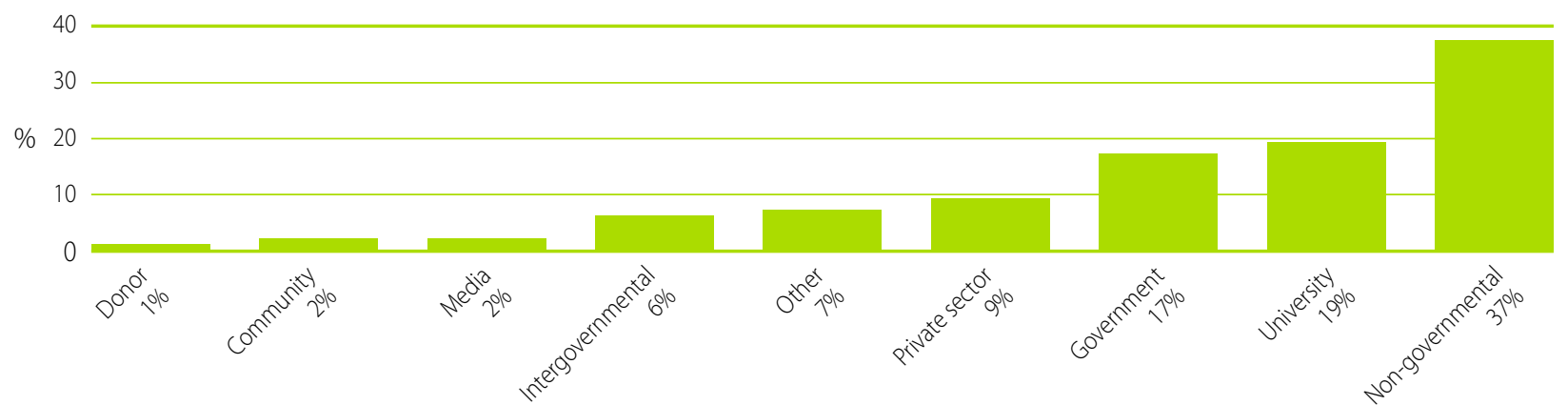

to provide inputs, information and guidance to negotiators. It was therefore promising that 30\% of the respondents to the internet survey were members of official delegations to the UNFCCC. Not all members of official delegations are negotiators, however, and official delegations include a range of representatives from government, the private sector, research institutions and NGOs.

\section{Why do people come to Forest Day?}

Internet survey respondents were asked to describe their aims for attending Forest Day. Responses fell into four broad groups:

\section{New information and staying up-to-date: many} participants said that their main aim was to keep up-to-date on current research on issues related to forests, REDD+ and climate change.

Networking: participants used Forest Day as an opportunity to meet contacts and colleagues with whom they do not have day-to-day contact. This included professional and personal networking with existing and new friends and colleagues; bringing together representatives of projects in different countries; business development and profile raising; and sourcing new projects and project partners.

\section{One respondent described his aims for attending Forest Day 4: "Have fun. Learn stuff. Meet people."}

\section{Following and influencing negotiations and} policy processes: respondents wished to learn about the progress of the UNFCCC negotiations and other policy processes, and at the same time, hoped that Forest Day would have an input to policy processes.

Dissemination of information: participants used side-events, booths, posters, presentations and informal discussions to disseminate the findings of their own research, raise the profile of their projects, and learn from the work of others. 
When asked whether Forest Day 4 had allowed participants to achieve their aims, a resounding $85 \%$ of respondents answered 'Yes'. Members of the official UNFCCC delegations were equally positive, with $86 \%$ saying Forest Day 4 had allowed them to meet their personal aims for the day.

When asked what could be improved after Forest Day 4, nearly one-fifth of respondents added comments and criticisms, which fell into four main areas:

- $\quad$ The choice of speakers was criticized for being political, insufficiently technical, and policyoriented rather than scientific.

- The sessions were described as unchallenging and insufficiently controversial.
- The subject matter was often seen as political rather than scientific, with too few practical lessons from the field.

- The structure of the day was reported as chaotic, as a result of early delays related to the security operation surrounding President Calderón of Mexico, and because there were too many parallel events.
"Forest Day has become more a networking event. I would appreciate more technical and scientific presentations instead of political and very general statements."

\section{Attendance at Forest Day 4 by region}

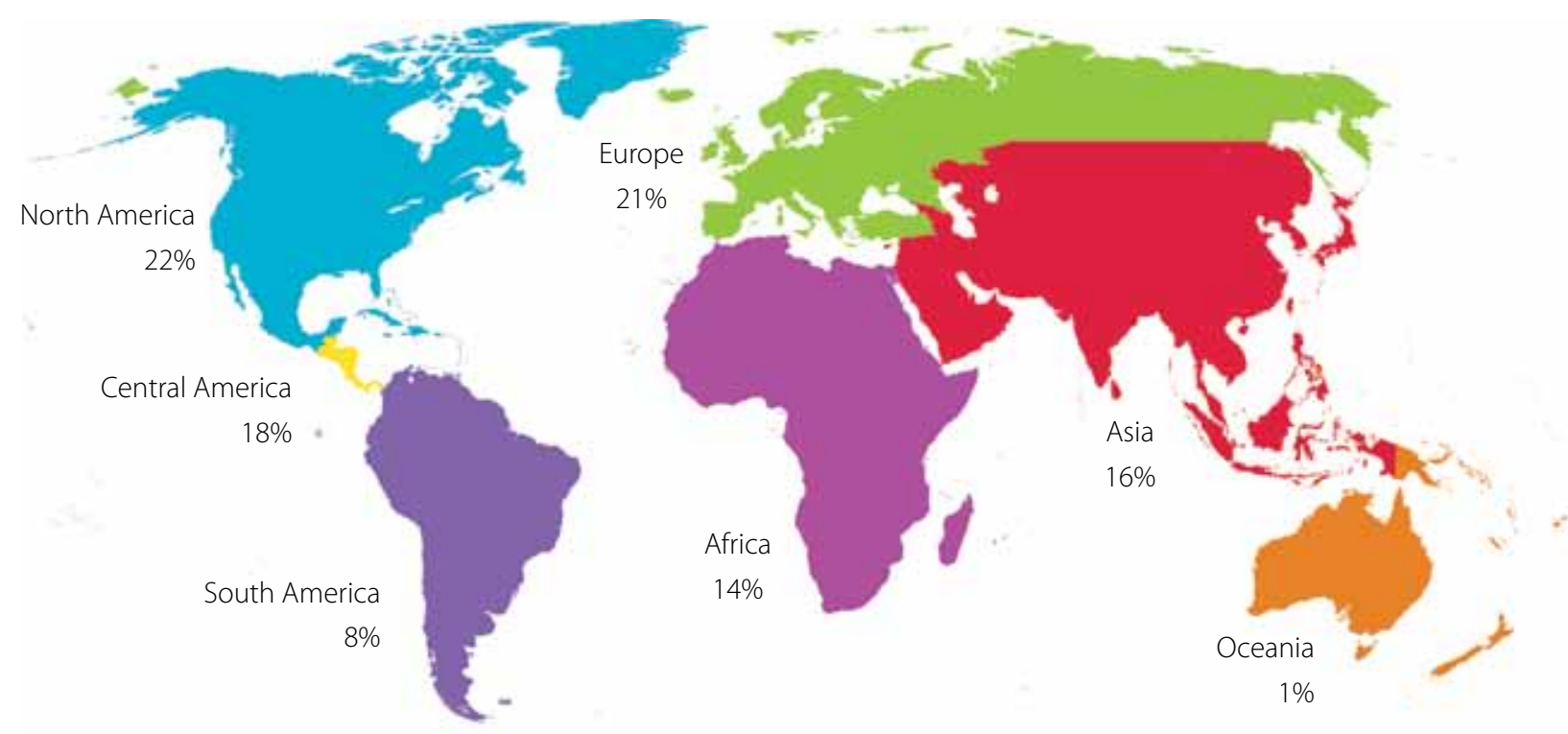




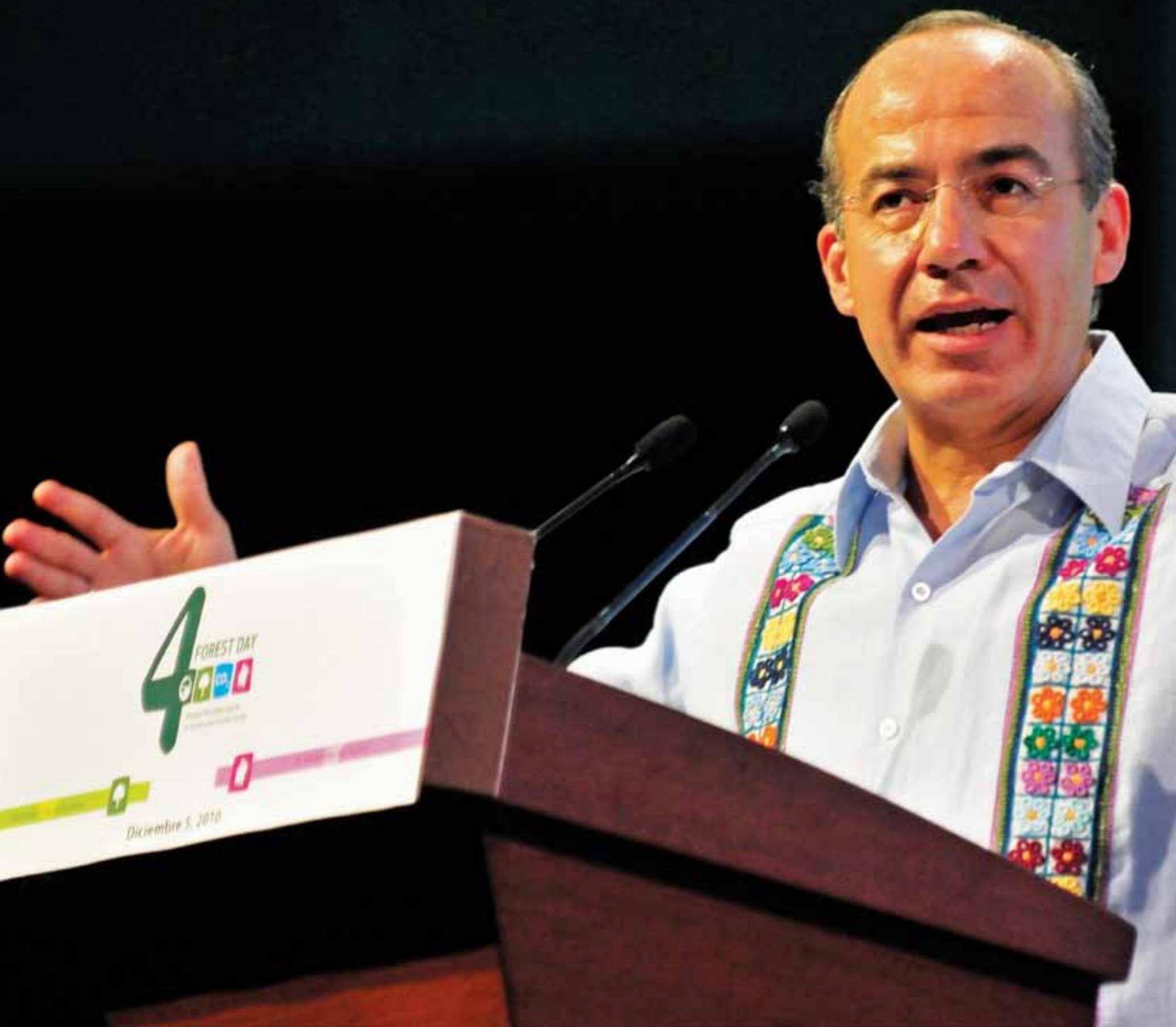




\section{Chapter 2 Identifying influence}

\section{What influence does Forest Day have?}

Forest Day was clearly successful in allowing the majority of participants to fulfill their own objectives. When asked to rate Forest Day 4 for its overall success, 95\% thought that it was either successful (55\%) or very successful (40\%) - a resounding endorsement of the day.

But what of the wider influences of Forest Day? Respondents to the internet survey were asked whether they knew of specific ways in which Forest Days 1 to 4 have had an impact. Overall, 36\% of all respondents gave a positive answer to this, rising to $38 \%$ among members of the official UNFCCC delegations. Nonetheless, it was difficult to pin down precisely what those impacts were perceived to be. The telephone interviews followed up on this question, and looked at four areas of possible influence. 


\section{Influence on UNFCCC negotiations}

One way in which Forest Day might have a

significant influence is through educating and informing UNFCCC negotiators themselves. The internet survey and interviews aimed to find out to what extent discussions at Forest Day had a direct influence on the negotiators and on discussions at the UNFCCC COP talks.

Of the UNFCCC delegates who responded to the internet survey, 34\% reported that Forest Day had had a major effect, and $51 \%$ said it had had a minor effect in shaping their position in negotiations or thinking about the issues. Thus, $85 \%$ of all members of official UNFCCC delegations who responded said

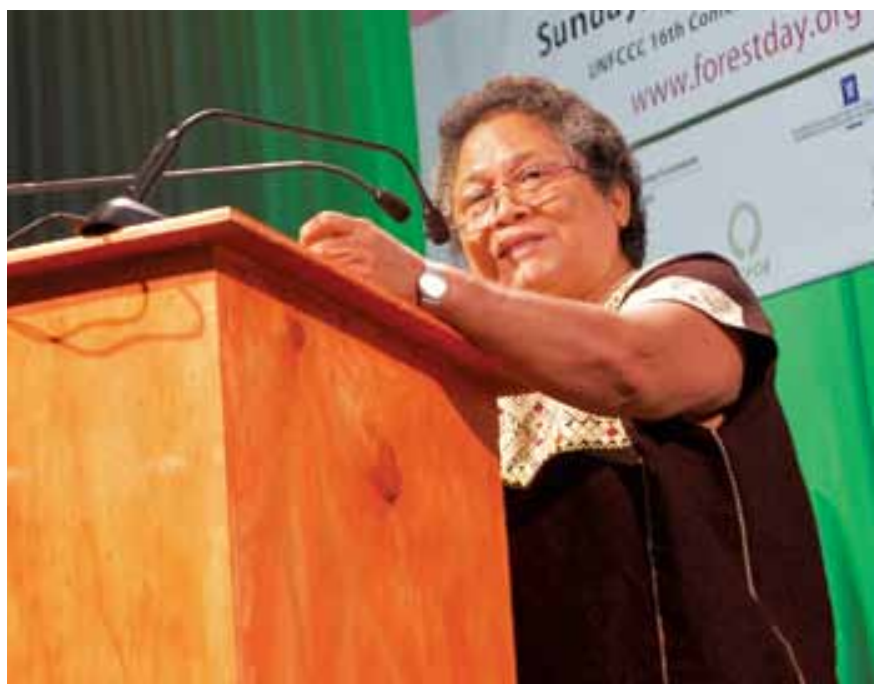

Myrna Cunningham, Chair of the Center for Autonomy and Development of Indigenous Peoples (CADPI) the Forest Day sessions they attended had helped shape their position to some degree.

Similarly, $85 \%$ of UNFCCC delegates also agreed or strongly agreed that Forest Day 4 had supported negotiators and other stakeholders to develop the next level in the design and implementation of REDD+ and other mitigation or adaptation schemes.

\section{“People attending Forest Day are experts on forestry, so you can learn from them on the whole range of forest science to policy issues."}

UNFCCC negotiators do not necessarily have a forestry background. This is especially true of those heading the delegations, who are often from a finance or economic background. Forest Day can therefore play an important role in providing forestry knowledge and information for these negotiators. Some of the UNFCCC negotiators interviewed remarked that Forest Day provides a good opportunity for non-specialists to understand important forestry concepts. One delegate remarked that Forest Day helped him grasp the importance of forests and REDD, as well as forests in the broader sense of ecosystems and protecting biodiversity, not just reducing emissions.

Forest Day is clearly appreciated. However, the interviews showed that the direct impact on the COP is not as great as it might be, for several reasons: 
Timing: Forest Day occurs too late in the COP process every year to have real influence on the discussions. The parties to the UNFCCC COP must give their opening views at the start of the first week of COP negotiations. Many possibilities are only open for discussion at this point, because UN rules do not permit parties to introduce new ideas to the text later on. Being held between the two weeks of the negotiations, Forest Day occurs too late in the negotiation process to influence the talks. Although timing was quite often mentioned as a disadvantage, some official negotiators do find the current timing helpful. Forest Day provides an opportunity between the two weeks of negotiations for feedback, for informal meetings with other delegations, and for meeting with others involved in forestry issues.

Clear policy messages: negotiators have difficulty translating what they hear at Forest Day into sound policies related to the UNFCCC processes. It would be helpful if the organizers of Forest Day could track the negotiation processes prior to the COP, identify the sensitive issues and the options for resolving them; and discuss them at Forest Day, or in background briefing documents beforehand.

Targeting top negotiators: the negotiating delegations consist of a range of people with technical as well as senior political backgrounds. Delegations tend to send the technical people to meetings like Forest Day. To have more influence, Forest Day needs to attract the senior politicians and to provide them with a strategic policy - rather than a scientific - angle to feed into the negotiations.
This point, however, contradicts many of the general responses to the internet survey, where many respondents suggested that Forest Day should have a more science-oriented focus.

Despite these reservations, some survey respondents and interviewees believed that Forest Day has played a fundamental role in pushing forward the REDD agenda.

\section{"Forest Day is bigger than the project level impacts: without Forest Day we wouldn't have an agreement at Cancún."}

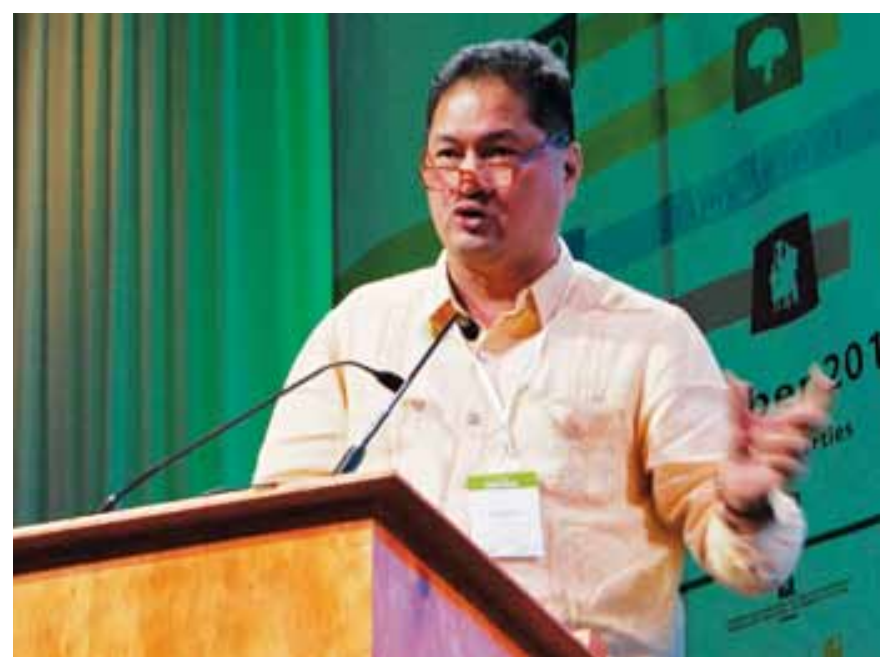

Antonio La Viña, JSD, Dean, Ateneo School of Government, Manila University 
But not all interviewees agreed that Forest Day should have a larger influence on the COP talks. One official delegate commented: "UNFCCC is a party-driven process, and this must be respected, so I do not recommend further synergies with the negotiations." Instead it was suggested that Forest Day should move away from its emphasis on REDD and carbon-related issues, and address payments for environmental services in general and a broader range of forestry topics. This was a minority view, but it highlights the need for the Collaborative Partnership on Forests to clearly decide whether a major aim of Forest Day should be to influence the UNFCCC process, and whether it should remain focused on REDD-related issues.

\section{Extent to which sessions at Forest Day helped shape participants' positions in negotiations or thinking about the issues}

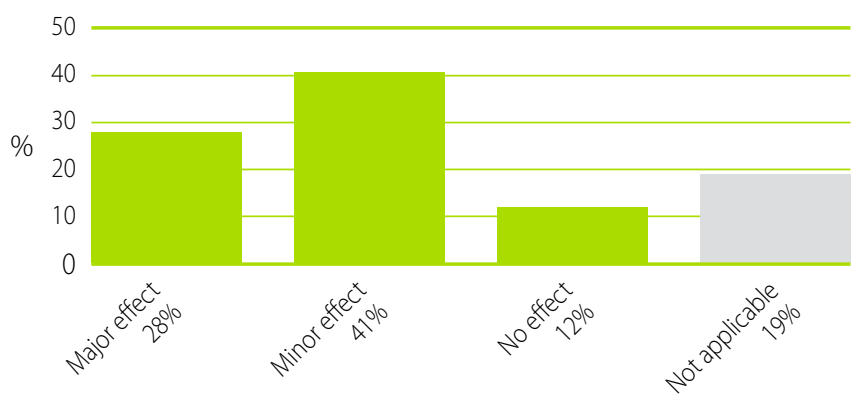

\section{Influence on participants' perceptions, thinking and negotiating positions}

According to the internet survey, Forest Day had an effect on the thinking or negotiating position of $69 \%$ of respondents. Overall, $28 \%$ of respondents said that Forest Day had had a major effect on their negotiating position or thinking on the issues, while a further $41 \%$ said it had a minor effect.

\section{"You can talk directly with top scientists, and learn directly from them."}

Direct access to high-level scientists' and experts' opinions was important in helping shape the views of many participants. This was especially true for those who did not have a forestry background or who did not work intimately with REDD and forest carbon issues. Forest Day also helped non-specialists understand wider forestry issues, bringing together information and ideas that would otherwise have taken a long time to gather.

Forest Day was credited with influencing interviewees' personal thinking by providing them with an opportunity to keep up with the latest thinking on forests and REDD-related issues. With so many disparate threads to the UNFCCC talks and to forest carbon issues in particular, Forest Day provides an opportunity to "take the pulse" of the situation and was described as "a learning experience in a dynamic environment". 
"While I had a fairly good foundation in carbon accounting and markets coming into Forest Day 4, the sessions on social aspects of REDD were very influential in rounding out my understanding of what will be needed for successful projects."

The presence of President Calderón of Mexico at Forest Day 4 was highlighted as personally influential by respondents at all three phases of the evaluation. They felt that it demonstrated recognition at the highest level of the COP hostcountry of the importance of forests in the UNFCCC.

For some, however, Forest Day is not so important for forming ideas or negotiating positions, particularly where these people work in the field and already have well developed ideas. For many of these people, the value of Forest Day lies in the networking opportunities it presents.

"All those who work on REDD+ are in an expanding consciousness, but there are no specific convictions that come from Forest Day."

\section{Influence on institutional policy, direction and outputs}

In addition to informing and influencing UNFCCC negotiators, and helping participants to develop their own thinking and negotiating positions, Forest Day may also have an influence on institutional policy, directions and output. Participants who attend Forest Day take knowledge home with them and apply it in their home institutions.

During the telephone interviews, the importance of this effect was discussed in more detail. Respondents were asked to identify ways in which Forest Day had influenced policy or practice, either at the level of their institution, or more broadly at local, national or international levels.

Several interviewees suggested that Forest Day (and (IFOR more generally) has been important in setting the framework for discussions about REDD, carbon and forests in general. People attending Forest Day saw the issues on the agenda as the set of 'live'

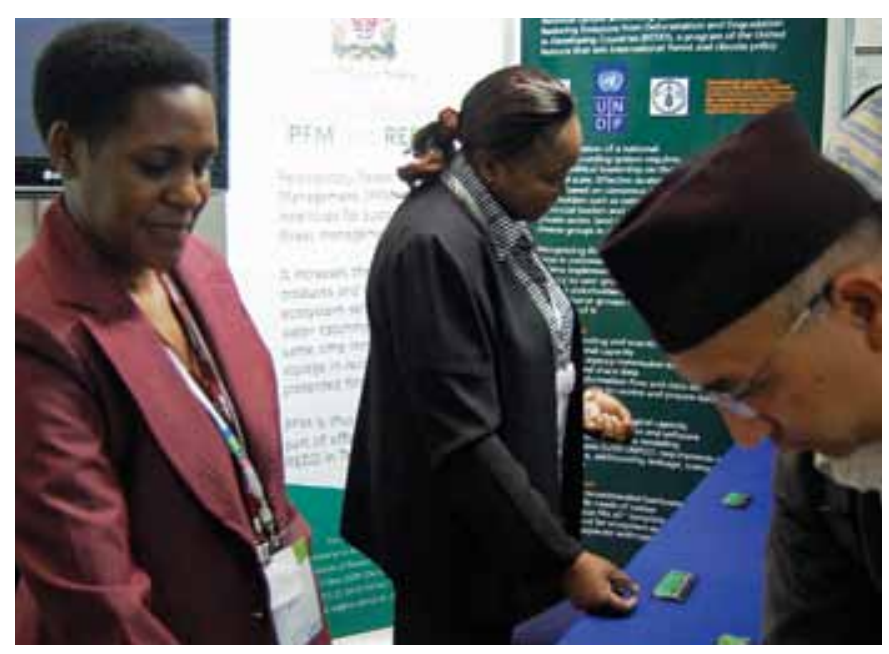

Many participants use Forest Day as an opportunity to disseminate information 
issues to discuss, and through this Forest Day has an impact on institutional policies.

In particular, Forest Day was credited with increasing the importance accorded to multi-stakeholder participation, rights and safeguards, both within the priorities of the UNFCCC processes and in the REDD-related activities of individual institutions. One interviewee noted that Forest Day has widened the scope of REDD to include transparency and accountability, and that this was now reflected in their own projects. Another noted that, as a result of Forest Day 4, his institution was thinking more about communication with, and participation of, local people in their projects, benefit sharing, and prior informed consent processes. The institution was considering what kinds of initiatives it should include in its projects to address these issues.

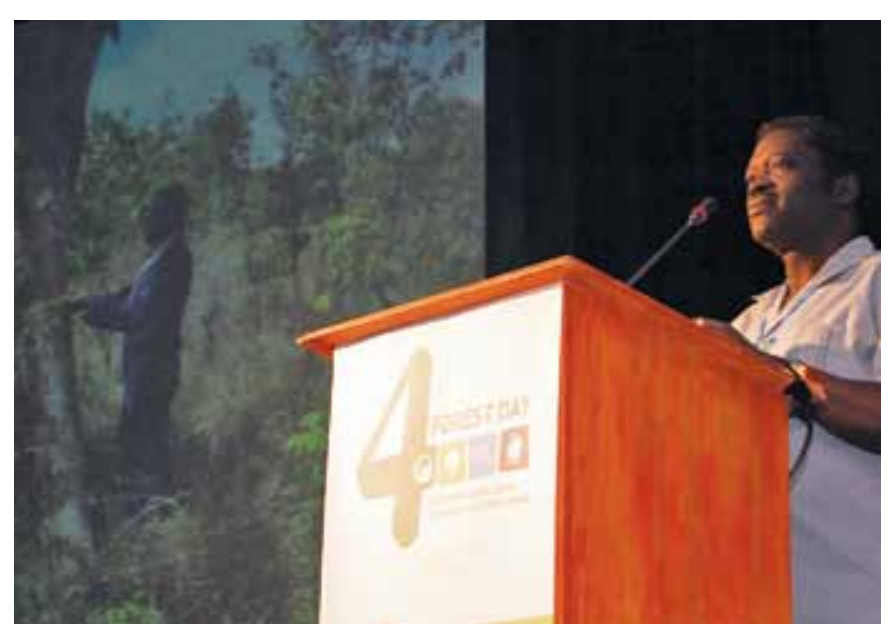

Forest Day 4 Parallel Learning Event

\section{“REDD+ was originally seen as just REDD. Forest Day helped position other topics and themes that became the +."}

Forest Day also reinforces the perception that forestry and REDD are areas that should be supported by donors. One private-sector donor noted that Forest Day helps them to maintain their focus in this area and to decide which issues and areas they will support in the future with their limited resources.

However, it was extremely difficult to pin down specific effects on institutions and their policies arising from Forest Day. Several interview respondents felt that, although Forest Day is an excellent platform for exchanging experiences and ideas, it does not have a real influence on decisions. The process by which ideas become influential is more nebulous, and cannot be attributed to a single day every year.

This is particularly the case at the level of national governmental policy. Here, positions are formed by wider processes, rather than Forest Day alone. For instance, one member of an official UNFCCC delegation said: "Bilateral and multilateral donors ... have had targeted approaches on reforming the forest policy framework".

And while information from Forest Day can provide useful background to inform ministers, it is not specific enough to use directly. "Most of the events and presentations and speeches on Forest 
Day are very general and the level of detail in such presentation and speeches really cannot be expected to influence policy direction."

\section{Influence on projects and partnerships}

Do new projects arise as a result of Forest Day? Are existing projects altered as a result of Forest Day? In the internet survey some respondents commented that they had made connections with other projects, developed new partnerships and made new contacts for research collaboration during the Forest Days that they had attended.

Telephone interviewees were asked whether they knew of specific projects that they would consider to be linked to, or a result of, Forest Day. A number of projects were identified, which had their genesis in meetings and contacts made at Forest Day: examples were mentioned in Bhutan, Congo, Guyana, Nepal, Tanzania, Uganda and Zambia.

Again, however, Forest Day was mostly credited with providing the opportunity for first contacts, which might - or might not - lead to new projects in the future. As one respondent put it: "Not a huge amount of money comes directly through Forest Day and the effect is hard to measure; it's usually just the initial contact, which may lead to something a few years on."

"There's a series of hops and links that may start off with a conversation at Forest Day."

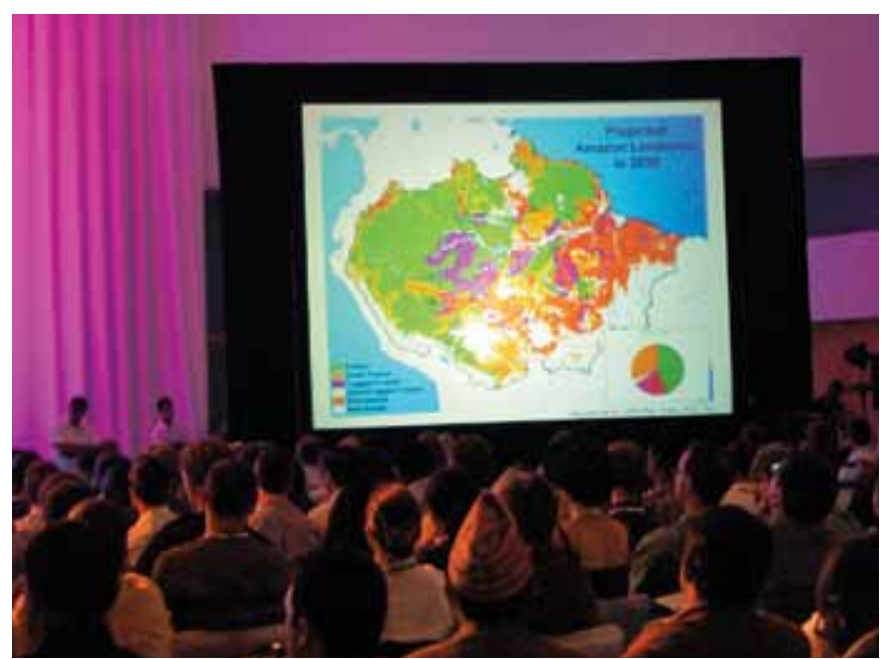

Forest Day 4 Parallel Learning Event

In general, interviewees found it hard to point to projects that were specifically the result of interactions at Forest Day. One government interviewee remarked that it was not possible to identify specific projects or programs that resulted from Forest Day. While this might be possible for smaller scale projects, at a national scale decisionmaking is too complex to be said to result solely from an event like Forest Day. 



\section{Chapter 3 Looking to the future}

\section{The positive response}

Throughout all three phases of the evaluation, many criticisms and suggestions were received for improvements that could be made to Forest Day to enhance its impact. This should not obscure the overwhelmingly positive response that Forest Day received.

Of the 290 people who rated Forest Day 4 in the internet survey, $95 \%$ thought that the event was either successful (55\%) or very successful (40\%). This is a very encouraging result, and confirmation - if any were needed other than the rising attendance figures - that the day is appreciated and felt to be worthwhile.

\section{"Of all the forestry and REDD things, it's the place to be!"}




\section{The future direction of Forest Day}

Given the positive response that Forest Day received from respondents to the surveys, there is no doubt that the majority of participants would like to see Forest Day continue into the future.

There was less consensus about the role that Forest Day should play. The balance between policy and science at Forest Day 4 emerged as a major theme in both the internet survey and the interviews. Many respondents to the internet survey expressed the view that Forest Day 4 was too focused on highlevel policy, with inadequate emphasis on research, science and practical examples from the field.

The interviews gave a more nuanced view of this interface, and several respondents (especially those from the official UNFCCC delegations) suggested that Forest Day needs to be more policy focused.

\section{Overall rating of Forest Day 4}

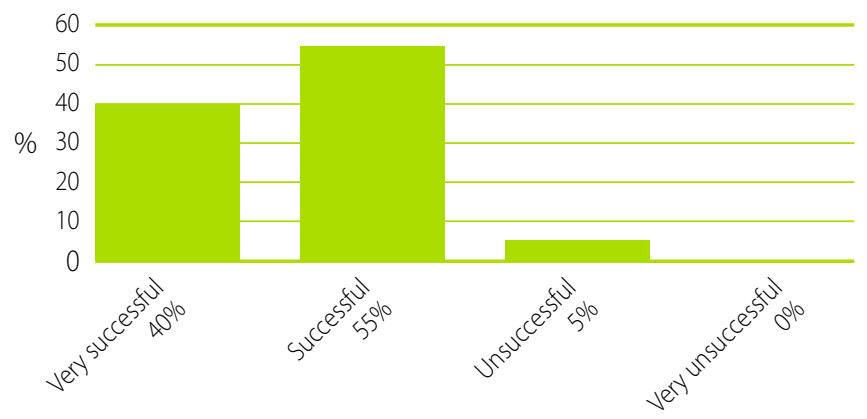

This presents some fundamental questions for the organizers of Forest Day: who is it for, and what do the organizers aim to achieve? Should Forest Day aim to have direct impacts on the COP negotiations, or is the aim really to convene a scientific gathering in order to share, discuss and push forward the scientific agenda?

If the aim is to draw in more policymakers and negotiators, and to have a more direct impact on the COP talks, Forest Day organizers need to take a strategic policy approach. This could involve tracking the negotiation process prior to the COP, identifying what is and is not possible, and discussing at Forest Day what can really be done in terms of negotiating policy. Organizing Forest Day to occur before the COP talks begin would also increase the opportunity to have a direct impact on the negotiations.

If the organizers of Forest Day wish to focus on the scientific and technical aspects of forests, climate change and REDD, the responses to the internet survey show that there is strong interest in such complex issues, and a desire to see some of the hard, controversial and technical issues addressed in detail. A great deal of interest was expressed in seeing more applied and adaptive research and experience from the field.

As REDD+ projects move forward in many countries around the world, there is a wealth of experience that needs to be gathered together to provide an overview of what works, what is needed and what is happening after the first round of UN-REDD and Forest Carbon Partnership Facility (FCPF) pilot projects. Forest Day is ideally placed to fulfill this need. 


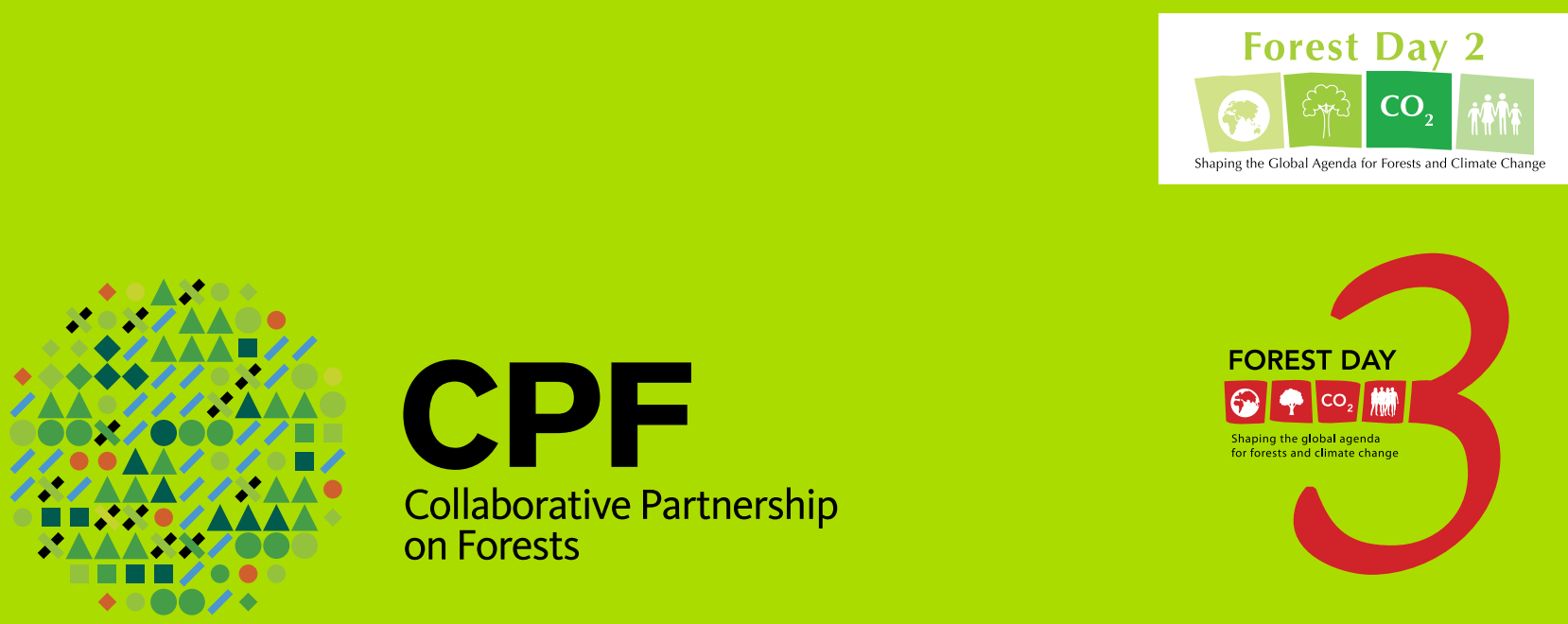

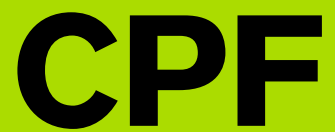

Collaborative Partnership on Forests

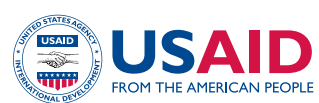

OMOORE

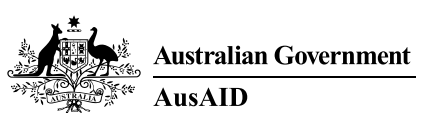

AusAID

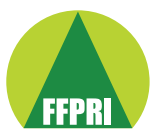

好 NORWEGIAN MINISTRY OF THE ENVIRONMENT PROFOR
Google earth engine

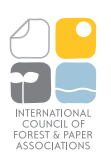

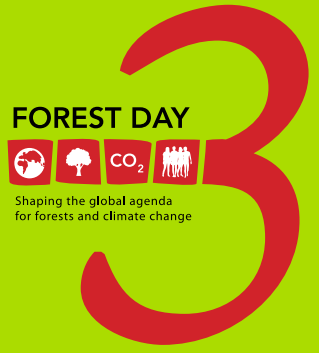

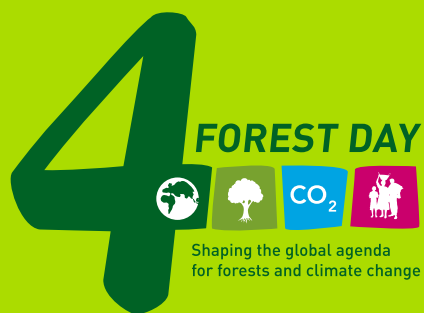

\section{Center for International Forestry Research}

CIFOR advances human wellbeing, environmental conservation and equity by conducting research to inform policies and practices that affect forests in developing countries. CIFOR is one of 15 centres within the Consultative Group on International Agricultural Research (CGIAR). CIFOR's headquarters are in Bogor, Indonesia. It also has offices in Asia, Africa and South America. 